\title{
This Wolfe isn't in sheep's clothing
}

$\mathrm{H}$ e's been called a drug safety gadfly, an extremist and an avowed anti-industry activist. He calls direct-to-consumer advertising of pharmaceuticals "emotion promotion" and his critics say he has never seen a drug he likes.

Call him what you will, but you won't find a guy who has a bigger public profile in the drug safety world than Dr. Sidney Wolfe of the consumer group United States Public Citizen, which Ralph Nader founded in the 1970s. As the head of the group's health research arm, Wolfe has sued or petitioned the US Food and Drug Administration (FDA) nearly 30 times over the past 38 years and has had a hand in helping push 16 drugs off the market (see www.worstpills.org).

Now, ironically, he's taken his drug safety advocacy inside the FDA as an appointed member of the regulator's Drug Safety and Risk Management Advisory Committee, which helps reassess the safety status of drugs. Wolfe has been an acting committee member since May 2008 and a full voting member since August, but in January he went public about his new position. I rang him at his office in Washington, DC, armed with a few choice tidbits trolled from the pharma blogosphere and asked him to respond to some of the main criticisms flung toward him and his organization over the years.

Cassels: Some have said your new appointment makes a joke out of the agency's new conflict-of-interest rules. Do you have any conflicts?

Wolfe: No, I don't have any [financial] conflicts of interest. ... What you're getting at is an intellectual conflict of interest, because I know something about these drugs. That's why I'm on $\vec{\infty}$ the committee. If it's a conflict to be concerned about drug safety, tell me what's the absence of concern about drug safety? I call that recklessness.

Cassels: You get accused of beating up drug companies.
Wolfe: We've never singled out individual drug companies. You look at any variable, number of drugs taken off the market, fraud, the withholding of information, they all engage in this. That is what we call the rhetoric from the right. They say things like that because they can't come up with anything objective.

Cassels: Are you keeping really useful drugs off the market?

Wolfe: I'd like to see some evidence for that. We strongly support breakthrough drugs getting approved. When AZT [zidovudine] was approved in less than a year, we thought that was a good idea. Here was something really new for a killer disease. If they [my critics] could cite 1 example of an important drug we kept from the market, I'd like to know what it is. This is more rhetoric from the right. They are devoid of examples, because there aren't any examples.

Cassels: This consortium that nominated you, who are they and who funds them?

Wolfe: [The purpose of the] consumer consortium ... is to nominate consumers for the consumer slot on the FDA's committees. It's a completely voluntary organization. I can't imagine why it would need any funding. It doesn't cost anything. They do the interviews by phone.

Cassels: How do you respond to the people who call you an extremist when it comes to the risks and benefits of medical treatments.

Wolfe: That's not supported by our record. We have never taken what anyone would call an extreme stance on the safety of any drug or device. I come from an academic medicine background. ... I spent most of my time in medical school doing research on drug toxicity. I had done enough research in medical school that I was able to get in the National Institutes of Health. I spent 5 years there doing medical research. I'm an aca-

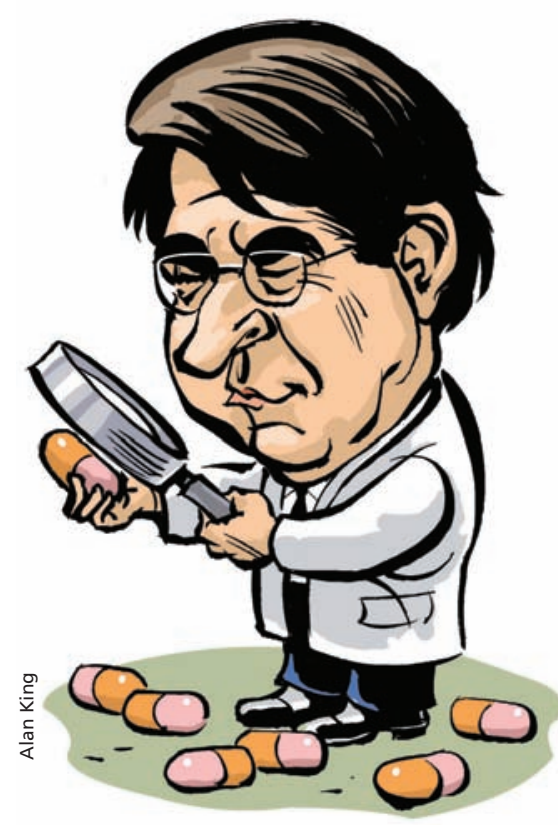

demic. I met Ralph Nader and there was a great need to translate research into action. That's what we've been doing: research-based advocacy. There are people both on the right and the left that aren't research based. If you're research based, then you are looking at data and making conclusions based on the data. If someone calls that an extremist then they've redefined extremist. That's their problem not mine. I am not an extremist.

Cassels: I've been accused of being an extremist as well. I know what that feels like.

Wolfe: The next time you're in Washington I'll buy you an Extremist beer.

Cassels: Excellent.

\section{Alan Cassels MPA \\ Victoria, BC}

Mr. Cassels' work as a pharmaceutical policy researcher at the University of Victoria is funded by public sources.

Have you got an opinion about this article? Post your views at www.cmaj.ca. Potential Salon contributors are welcome to send a query to salon@cmaj.ca 